\title{
A Critical Review of the Oversight Role of the Office of the Auditor-General in Financial Accountability
}

NZEWI, Ogochukwu | MUSOKERU, Prosper

\section{Abstract}

ccountability is the very essence of
the Constitution of the Republic of South Africa (Act No. 108 of 1996). In this regard, the Auditor-General of South Africa (AGSA) as the supreme audit institution of the Republic of South Africa plays an important oversight role of promoting financial accountability in government. The purpose of this article is to examine the challenges facing the office of the Auditor-General in executing its oversight role of promoting financial accountability in the sphere of provincial government. Information and sources for this article was gathered through literature review. The article gives some background on the establishment and rationale of Supreme Audit Institutions (SAI). It explores some policy framework that informs public finance management in the Republic of South Africa, establishing the role of the AGSA within this purview. Based on the data gathered through literature review, the key challenges facing the office of the Auditor-General are discussed. Finally, possible solutions are recommended to the challenges that were identified.

Keywords: Public Accountability, Financial Accountability, Government Institutions, Oversight Role.

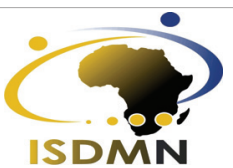




\section{Introduction}

The purpose of this article is to investigate the challenges faced by the office of the Auditor-General in promoting financial accountability in the Eastern Cape provincial government. Financial accountability is a means of ensuring that public money has been used in a responsible and productive way. It is about verification of legality and regularity of financial accounts, but also about making sure that value for money has been achieved in the use of resources (Van der Waldt et al., 2002: 40). Financial accountability in South Africa originates from the Constitution (1996). Every public institution and functionary is held responsible to perform certain functions. Therefore, financial accountability is the means to ensure that finances are managed in an efficient, effective and economic manner and that those responsible for the use of funds are held answerable. The office of the Auditor-General South Africa (AGSA) plays an oversight role in this regards.

The research methodology is qualitative in nature and multiple sources of information have been used. It is based on the analysis of secondary sources of data which cover a wide spectrum of themes, including published core literature on the topic, reports of the Auditor General, theories and approaches of accountability, the relevant legislation, regulations, official documents, policy documents, journal articles and internet websites. The article starts with a brief outline of the background to the study, followed by a discussion of the legislative frameworks that guide public finance management, and a summary of the role of the Auditor-General in financial accountability, before venturing on the thematic discussion of the findings and the way forward stemming from the study.

\section{Background to the study}

An important point of departure in constructing democratic institutions is that the citizens of a country should be able to hold their representatives accountable. Public financial accountability requires that governments manage finances prudently; that they integrate their financial and nonfinancial reporting, control, budgeting, and performance; that they report comprehensively on what they have achieved with their expenditure of 
funds and that stakeholders behave ethically (Sahgal and Chakrapani, 2000: 3). To fulfil this demand, governments rely on independent audit of public operations which is done by the Supreme Audit Institutions (SAI) in all countries. These SAIs are all governed by international standards of accounting. According to Obto (2005: 3), there is a process for setting auditing standards for SAIs. The organization responsible for this process is the International Organization of Supreme Audit Institutions (INTOSAI). In South Africa, the chief responsibility for financial monitoring of government lies with the Office of the Auditor General. The Constitution of the Republic of South Africa (Act No. 108 of 1996) calls for an Auditor-General who will audit and report on the accounts, financial statements and financial management of all national, provincial and local state departments and administrations, including all municipalities and other institutions. Being the SAI of the State, the Office of the Auditor-General performs the function of watchdog in ensuring public financial accountability.

The Auditor-General was established on 31 May 1910 as a result of the South Africa Act of 1909 (AG, 2011a: 8). According to the AG (2011a: 8), it became operational on 12 May 1911 with the commencement of the Exchequer and Audit Act, 1911 (Act No. 21 of 1911). In 1993 the Amendment Act (Act No. 123 of 1992) granted the AG full independence from government, which gave the organisation the requisite autonomy to execute its mandate fully without favour or prejudice (AG, 2011a: 8).

In 1994, as part of the transitional process, the democratic government incorporated the most appropriate elements of public auditing from the past into the new dispensation. Indeed, since 1994, the AG as the SAI of the Republic of South Africa has grown into a respected pillar of the country's democratic architecture. The Constitution of the Republic of South Africa (1996) provided for the Auditor-General South Africa (AGSA). The AGSA is established in terms of section 181 (1) (e) of the Constitution of the Republic of South Africa (1996) as a state institution supporting constitutional democracy. It has a constitutional mandate and as the SAI of the country it exists to strengthen the country's democracy by enabling oversight, accountability and governance in the public sector, thereby building the public confidence. 
A Critical Review of the Oversight Role of the Office of the Auditor-General 39

\section{Legislation informing financial accountability in South Africa}

Since the dawn of democracy in 1994, the Republic of South Africa has taken many positive strides to transform the public sector so as to improve public finance management. The Parliament developed the following significant laws that guide public finance management and promotes accountability and transparency:

- Constitution of the Republic of South Africa 1996 (Act No. 108 of 1996);

- Public Finance Management Act, 1999 (Act No. 1 of 1999 as amended by Act No. 29 of 1999) (PFMA);

- Local Government: Municipal Finance Management Act, 2003 (Act No. 56 of 2003) (MFMA);

- Public Audit Act, 2004 (Act No. 25 of 2004);

- Auditor-General Act, 1995 (Act No. 12 of 1995).

The relevant constitutional provisions that refer directly and indirectly to accountability are as follows: Section 215 (1) of the Constitution (1996) provides that national, local and municipal budgets and budgetary processes must promote transparency, accountability and the effective financial management of the economy, debt and the public sector. To this end, the Constitution of the Republic of South Africa (1996) provides a platform for sound financial accountability in the country. The PFMA is one of the most important pieces of legislation passed by the first democratic government in South Africa. The Act exists to promote the objective of good financial management in order to maximize service delivery through the efficient and effective use of the limited resources.

PFMA establishes the National Treasury which monitors implementation of provincial budgets, coordinate intergovernmental and fiscal relations and promote and enforce transparency and effective management in respect of revenue, expenditure, assets and liabilities of departments, public entities and constitutional institutions among others. The key objective of the PFMA is to ensure that public sector managers efficiently manage, but at the same time be held accountable. The Act makes it clear that the government is very serious about the implementation and maintenance of internal 
controls and therefore, the proper accountability of public officials to the extent that provisions for financial misconduct and criminal offences were included in this Act. The Act attempts to modernize public finance management in the Republic of South Africa.

Furthermore, the Municipal Finance Management Act, 2003 (Act No. 56 of 2003) seeks to ensure sound and sustainable management of the financial affairs of municipalities and other institutions in the local sphere of government to establish treasury norms and standards for the local sphere of government. The object of MFMA is to secure sound and sustainable management of the fiscal and financial affairs of municipalities and municipal entities by establishing norms and standards and other requirements for ensuring transparency and accountability and appropriate lines of responsibility in the fiscal and financial affairs of municipalities.

Additionally, Public Audit Act, 2004 (Act No. 25 of 2004) was established to give effect to the provisions of the Constitution of the Republic of South Africa (1996), establishing and assigning the functions of the Auditor General. The Act also provides for the auditing of institutions in the public sector and for accountability arrangements of the Auditor-General to repeal certain obsolete legislation.

Finally, Auditor-General Act, 1995 (Act No. 12 of 1995) establishes the requirement for the appointment of the Auditor-General and outlines his or her functions, duties and powers. The Office of the Auditor-General in effect audits and investigates all accounts of the public entities and report to Parliament on the findings.

The above mentioned legislative frameworks aim to secure transparency, accountability and sound management of the finances of government departments. Also, they govern public financial management thereby enhancing the oversight role of Parliament of promoting financial accountability. In this regard, Parliament uses the Office of the Auditor-General as an accountability mechanism to perform the oversight role.

\section{The role of the office of the Auditor-General in ensuring financial accountability}

The Constitution of the Republic of South Africa (1996) Section 188 (1) provides that the Auditor-General must audit and report on the accounts, financial statements and financial management of all national and provincial state departments and administration, all municipalities and any other institution or accounting entity required 
by national or provincial legislation to be audited by the Auditor General. In terms of the Public Audit Act, 2004 (Act No. 25 of 2004), the Auditor-General is responsible for financial management and control in all the spheres (national, provincial and local) of government. The financial control happens through its auditing expenditure of all the spheres of government. The main function of the Auditor-General is to ensure that correct accounting procedures and standards are followed with regards to expenditure and revenue reported. The Auditor-General Act, 1995 (Act No. 12 of 1995) provides that the Auditor-General have a right to investigate and to enquire into any matter, including the efficiency and effectiveness of internal control and management measures relating to expenditure by and the revenue of an institution whose accounts are being audited. The Act further states that the Auditor-General have a right to investigate whether any property, money, stamps, securities, equipment, stores, trust money, trust property and other assets of an institution whose accounts are being audited by him or her have been obtained in an economical manner, and are being applied efficiently and effectively.

Moreover, the Auditor-General is required in terms of Section 20 of the Public Audit Act, 2004 (Act No. 25 of 2004) to indicate:

(a) whether the annual financial statements of the auditee fairly present, in all material respects, the financial position at a specific date and results of its operations and cash flow for the period which ended on that date in accordance with applicable financial framework and legislation,

(b) the auditee's compliance with any applicable legislation relating to matters, financial management and other related matters, and

(c) the reported information relating to the performance of the auditee against predetermined objectives".

To this end, the review of public audit frameworks in South Africa locates the AGSA as the supreme audit institution, constitutionally mandated to table annual reports to Parliament on the accounts and financial management of all government departments and state institutions. Thus, the role of the Auditor-General is to provide an independent oversight role of government operations through financial and other management audits. The Auditor-General has a crucial role in enforcing accountability by producing 
audit reports and make recommendations to public agencies on how to strengthen their financial management systems.

Previous research indicates that despite their critical role in enforcing accountability, Supreme Audit Institutions (SAIs) are beset with severe institutional and operational limitations and the AGSA as the SAI of South Africa has no exception. Ramkumar and Krafchik (2005: 6) argue that in some countries, the SAI is not created by legislation that provides adequate independence and freedom from executive interference. Even in cases in which SAIs have sufficient audit mandate, they may lack additional investigative powers to enable them follow up on apparent violations and ensure prosecution of relevant agencies or individuals (Ramkumar and Krafchik, 2005: 6). These are some of the challenges faced by the SAIs. Although the office of the Auditor-General South Africa has in the past years proved to be quite effective in exposing corruption and the unaccountable manner in which government resources are used, the office experiences a lack of authority to ensure that the executive acts on the recommendations of the Auditor-General (Van der Waldt et al., 2002: 273).

While substantial anecdotal evidence of these problems is widely known and cited, this article in the following section provides concrete evidence of the challenges faced by the office of the Auditor-General in playing its oversight role of ensuring financial accountability in the Eastern Cape Province. The Eastern Cape provincial government comprises 27 auditees, consisting of 15 departments (which include the provincial legislature and the provincial revenue fund) and 12 public entities (AG, 2012: 27). All these auditees are audited by the AGSA in order to enhance public financial accountability in the province.

\section{Challenges facing the office of the Auditor-General}

The AGSA is an important state institution that exists to strengthen constitutional democracy and to promote financial accountability in the public sector. According to the Constitution of the Republic of South Africa (1996), the Auditor-General audits and reports on the financial statements and financial management of government departments and institutions in all the three spheres of government. However, in carrying out its constitutional mandate of ensuring public financial accountability, the 
office of the Auditor-General faces a number of institutional, capacity, structural and technical challenges and threats, and these are discussed at length below.

\section{Political challenges}

Before one can explain the political challenges besetting the office of the $A G$ in executing its duties, it is imperative to first establish what is meant by politics. Van Niekerk, et al., (2001: 331) define politics as an aspect that is concerned with the use of state power. It is the actions that certain role players take to ensure that policies and procedures are or are not implemented (Van Niekerk et al., 2001: 331). According to Fox and Meyer (1995: 98), politics refers to the process by which power is applied to determine whether and how government is to be executed in any given area. Thus politics is all about the use of power and authority to govern.

The political challenge facing the AGSA is that it lacks sufficient authority to ensure that audit findings and recommendations are acted on. Visser and Erasmus (2002: 46) argue that it is important to note that the Auditor-General's authority ends with the report and recommendations made to Parliament on each audited department. The AG has no legal authority to prosecute or dispense disciplinary action; this is left to other public institutions such as the Director of Public Prosecutors and the Public Protector (Visser and Erasmus, 2002: 46). Van der Waldt et al., (2002: 273) provide that "the office of Auditor-General has in the last years proved to be quite effective in exposing corruption and the unaccountable manner in which government resources are used." Unfortunately, the office experiences a lack of authority to ensure that the executive acts on the recommendations of the Auditor-General (Van der Waldt et al, 2002: 273). While the Auditor-General provides reports and recommendations to the legislative body, these reports are rarely debated in Parliament (Van der Waldt et al, 2002: 273). The lack of power and authority to enforce recommendations is a major challenge to the functioning of the office of the $A G$; thus resulting in other resolutions aimed at improving financial accountability not being implemented. Although the $A G^{\prime} s$ annual reports offer distressing insights into weak governmental financial systems, the AG can only make recommendations. 


\section{Africa's Public Service Delivery \& Performance Review}

From an operational standpoint, local political and leadership dynamics hinder the work of the office of the AG. For instance, the Auditor-General (2011b: 13) provides that the reasons for slow progress towards clean audits in Eastern Cape can be found in the fact that around half of the political leaders at municipal level have not been responsive to the messages of the AGSA. Operation clean audit was launched by government in 2009 to address the poor audit outcomes of local government in the country (AG, 2011d: 13). The AG (2011b: 13) provides that, "without a positive and committed reaction from mayors and councillors, opportunities to build a sustainable culture of accountability at municipal level remain limited." The AG (2011b: 26) further argues that political instability in some municipalities diverts the attention of the council away from financial management and its oversight role.

The Auditor-General (2011b: 31) also provides that, "the leadership did not support governance structures in order to strengthen control environments. In some cases these structures complied with the legislative requirements, however, information was not always provided to internal audit units to enable them to conduct their audits. Internal audits reports were not responded to at all or were responded to too late for appropriate actions to be implemented, while recommendations were not implemented, resulting in repeat findings during follow up audits." The political leadership's will to improve audit outcomes at some municipalities is not evident and the assistance provided is therefore not bearing fruit (AG, 2011b: 72). This shows a lack of political will on part of leadership in the provincial government. According to the AG (2011b: 31) all success stories are based on the leadership of auditees implementing three elements, namely a leadership tone depicting a willingness to accept accountability for financial management throughout the financial year, creating a control environment that is conducive to accountability and oversight and decisive action plans with clear time frames to address the root causes of continuous qualifications and the continuous monitoring. Unsurprisingly, these very same best practices that form the foundation for the move to clean administration are not found in the auditees that were qualified (AG, 2011b: 31). According to the Parliament of the Republic of South Africa (2012: 24) the lack of oversight by the municipal leadership and the provincial Corporative Governance and Traditional Affairs is one of the findings in the audit outcome reports. The AGSA indicated that experience has taught them that when the country's political leadership sets the right tone and acts on AG's audit findings and recommendations, the results 
tend to be positive hence the emphasis on the key objective of visibility of leadership in the AG's strategic plan (Parliament, 2012: 24). To this end, lack of adequate monitoring and follow up of audit findings is a major challenge affecting the work of the AGSA. Control over public funds is not effective if audit queries and recommendations are not followed up by parliament and acted on by the executive.

\section{Institutional challenges}

Among many key institutional challenges faced by the office of the Auditor-General in the past years have been the following: filling significant vacancies within the audit environment, strengthening the leadership focus on operational and strategic focus areas, improving the operating environment and positioning the Auditor-General as an example of accurate and transparent reporting on both qualitative and quantitative aspects of its work (AG, 2008: 26). The AG (2008: 26) argues that, "we continue to be inspired by the core challenge of identifying good talent and strive to nurture and grow our people internally as we grapple with the key vacancy challenges." Some of the institutional challenges facing the office of the Auditor-General in promoting financial accountability are as follows:

\section{Retention of staff}

According to the AG (2009a: 9), attracting and retaining sufficient qualified skilled staff is becoming increasingly difficult for the AGSA given the scarcity of accounting and auditing professionals in South Africa. Thus, the AG operates in an environment where skills are scarce and there is high mobility among professionals with those required skills. Staff retention is a major challenge for the office of the $A G$, as was clear from the high staff turnover in 2007-2008 (AG, 2008: 47). During this period the AG achieved an average labour turnover rate of $20 \%$ which was well above the financial service sector (including audit firms) average turnover of $16 \%$ (AG, 2008: 47). To build the AG's auditing and accounting skill base, which directly affects its mandate, the organization has for some time been investing in Trainee Accountant Scheme (TA Scheme) (AG, 2009a: 9). Recruitment for the TA scheme which also addresses employment equity requirements is now being driven in conjunction with an improved retention strategy 


\section{Africa's Public Service Delivery \& Performance Review}

(AG, 2009a: 10). More so, the AG started looking offshore for auditing skills to augment its capacity (AG, 2009a: 10). According to the AG (2009a: 10), while some degree of outsourcing is a necessity considering the workload of the $A G$, the current vacancy rate is counterproductive. It compels the organization to draw disproportionately on outsourced skills, which adversely affects cash flow management and financial sustainability of the institution (AG, 2009a: 10).

\section{The cost of auditing}

Another institutional challenge threatening the work of the office of the Auditor-General is the cost of auditing. The cost of auditing to the government is driven by a combination of factors, those which are controllable and those which are not (AG, 2008: 31). The factors over which the AG has significant control and which drive the cost of auditing include the following:

- the span of control within the audit business units and audit teams,

- the ratio between work performed by the AG's own staff (own hours) and that contracted out to private audit firms (contact work),

- the recovery of time ratio of individuals within the audit teams,

- the tariff structure for own staff and those of private audit firms and the operational efficiency of the audit methods and administration systems used by the AG (AG, 2008: 31).

The largely uncontrollable factors include the scope, size and complexity of the entity being audited, the inherent risks relating to the nature of activities of the entity and the maturity of financial management capability within the entity (AG, 2008: 31). All these factors provide challenges and threaten the work of the office of the Auditor-General.

The Auditor-General (2009a: 9) states that "another ongoing challenge is the need for continuous improvement of the AG's business processes to ensure that they are efficient and cost effective, and support effective risk management and decision making." According to the Auditor-General (2008: 31), the total cost of auditing increased from R893, 8 million in 2006-2007 to R1 109 million in 2007-2008. This increase is argued to have exceeded the 2007-2008 budget by R95, 7 million or 9, 4\% (AG, 2008: 31).

Another factor that contributes to increase in cost of auditing is the increase in contract work. Contract work increased by $67 \%$ as a result of the actual audit staff 
vacancies and staff turnover being higher than anticipated ( $A G, 2008$ : 32). The contracting out strategy assists the $A G$ in managing workload during peak periods and limits idle time during low periods. The additional contract work should also be viewed in the context of the staff turnover and the challenge of attracting and retaining qualified candidates in a highly competitive market (AG, 2008: 32). Furthermore, the AG provides that "tariffs increased by $1 \%$ due to alignment with market-related salaries, additional overtime and premium paid for temporary staff (AG, 2008: 32). As a result the cost of auditing continues to be a major challenge that threatens the work of the office of the Auditor-General.

\section{Debt collection}

According to the office of the Auditor-General (AG, 2009a: 9), the management of the Auditor-General's working capital and liquidity has become an area of serious concern over the years. Delays in debt collection, which is a key element of working capital, have resulted in serious cash flow problems for the organization (AG, 2009a: 9). The Parliament of the Republic of South Africa (2012: 14) provides that at the end of the 2011/2012 financial year, the total outstanding debt was R480 million compared to 31 March 2011. This indicates that a number of auditees are not paying their audit fees on time or not paying at all. Parliament (2012: 15) states that the local government on 31 March 2011 was still owing R206 million of the total outstanding debts of R480 million, the national departments owing R63 million and the provincial departments owing R124 million. This presents a major challenge to the work of AGSA as far as capital management is concerned since it heavily relies on audit fees because it does not receive allocation from the national budget (Parliament, 2012: 20). The ability of local government and statutory bodies to settle their accounts on time remains of grave concern (AG, 2007: 34).

Ongoing challenges in collecting outstanding cash balances which are concentrated largely within certain municipalities greatly affect the work of the office of the AG (AG, 2007: 34). However, the office of the AG continues to exercise strict control measures over debt collection through increased efforts and daily monitoring of payments (AG, 2011c: 8). This also includes the escalation of specific municipal debts to treasuries and 
political principals (AG 2011c: 8). The debt collecting challenges to the office of the AG also have an impact on the Office's ability to pay its creditors in time. The AG (2010a: 55) argues that during the 2009-2010 financial year, the rate of compliance with creditors' payment terms was $70 \%$ which was below the target of $80 \%$. This threatens the reputation of the AG to its creditors.

\section{Non-compliance with legislation}

Amongst the serious challenges facing the office of the $A G$ is that most institutions and departments in provincial government do not comply with all the relevant pieces of legislation that govern public finance management. This section will use examples of non-compliance with legislation from the Eastern Cape provincial government.

In the General Report on the Provincial audit outcomes of Eastern Cape Provincial Government 2010-2011, the Auditor-General states that, "compliance refers to adherence by auditees to the regulations to which they are subject. Conversely, non-compliance refers to acts of omission or commission by auditees, either intentional or nonintentional" (AG, 2011e: 23). Non-compliance with laws, rules and regulations is rife in the Eastern Cape provincial government and the $A G$, more often than not, strongly regrets this. The AG (2010b: 7) provides that a trend of non-adherence to laws and regulations appears to be prevalent within the Eastern Cape provincial government. The Eastern Cape provincial government comprises 27 auditees, consisting of 15 departments (which include the provincial legislature and the provincial revenue fund) and 12 public entities (AG, 2012: 27). The most prevalent issues relating to compliance with laws and regulations are the non-adherence to supply chain management policies and procedures, making payments within the prescribed periods and the audit committee as well as internal audit not fulfilling their legislative duties (AG, 2010b: 7).

In 2010, non-compliance with supply chain management principles that resulted in irregular expenditure was reported in the audit reports and financial statements of nine Eastern Cape provincial departments (Agriculture, Economic Development and Environment Affairs, Education, Health, Human Settlements, Public Works, Roads and Transport, Safety and Liaison, Social development) and seven provincial entities (Eastern Cape Arts and Culture Council, Eastern Cape Gambling and Betting Board, Eastern Cape Liquor Board, Eastern Cape Rural Finance Corporation, Eastern Cape Tourism, Eastern 
Cape Youth Commission, Mayibuye Transport Corporation (AG, 2010b: 30). This noncompliance with supply chain management precepts resulted in irregular expenditure of R2, 3 billion being incurred, constituting $78 \%$ of the total irregular expenditure incurred by the province in 2010 (AG, 2010b: 10). The accounting officers of three departments (Public Works, Roads and Transport and Social Development) condoned irregular expenditure totalling R90, 6 million for the 2008-2009 financial year which arose as a result of non-compliance with the supply chain management prescripts (AG, 2009b: 27). The AG (2009b: 27) argues that the level of non-compliance with the supply chain management regulations and the resultant irregular expenditure are indicative of potential fraud risks in the procurement processes of the affected departments.

Furthermore, the AG faces the challenge of departments not complying with all requirements for effective human resources management. According to the AG (2010b: 10), during the 2009-10 financial year, all 13 Eastern Cape provincial departments (legislature excluded) (100\%) did not comply with all the requirements for effective human resources management. These weaknesses impact on the department's financial management and their ability to deliver services in accordance of their mandate (AG, 2010b: 10). More so, all the 13 departments did not meet all the requirements for control over compensation of employees, and these weaknesses could lead to employees receiving compensation and benefits they are not entitled to (AG, 2010b: 10).

Departments and public entities are required by the PFMA to submit their financial statements for auditing by 31 May annually and the AGSA is required to complete an audit within two months of receipt of the financial statements. However, by the deadline of 31 May 2011, 14 (93\%) departments had submitted their financial statements for auditing (AG, 2011e: 12). The department of Education is the only auditee within the Eastern Cape portfolio that submitted financial statements after the prescribed date (AG, 2011e: 12). According to the Auditor-General (2011b: 26), there is a tendency of devious compliance in submitting annual financial statements with the expectation that corrections will be identified by the audit team and corrected during the audit process.

The most common PFMA non-compliance reported at departments related to delays in the payment of creditors beyond the 30-day period, while the most common PFMA non-compliance at public entities related to the failure to prevent irregular as well as 


\section{Africa's Public Service Delivery \& Performance Review}

fruitless and wasteful expenditure (AG, 2009b: 7). In terms of Section 38 (1) (c) (ii) of the PFMA, the accounting officer of a department must take effective and appropriate steps to prevent unauthorized, irregular and fruitless and wasteful expenditure and losses resulting from criminal conduct. The PFMA and the MFMA and the Public Audit Act, 2004 (Act No. 25 of 2004) set stringent reporting requirements for all auditees and it is evident from the foregone discussion that not all of them manage to meet their deadlines.

The deadlines of the AG are directly affected by the internal deadlines of the auditees (AG, 2008: 33). Receiving financial statements after the prescribed deadlines not only impacts the ability of the office of the AG to perform its functions in this regard, but could ultimately impede the ability of departments to perform within the accountability framework. Despite the AG having taken a proactive approach in dealing with auditees by increasing the number of audits, planning for audits and tracking audit progress in order to meet all legislative deadlines, delays did occur (AG, 2008: 33). Non-compliance with the relevant legislative frameworks that guides financial management is a major challenge to the tasks of the office of the AG. Late submission and/or non-submission of annual performance reports by entities prevent the AG from being able to execute all the relevant audit programmes effectively. For instance, the audit of the Eastern Cape Provincial Revenue Fund for the 2009-2010 financial year was not finalized at the legislated deadline as the financial statements were not submitted to the AuditorGeneral for auditing (AG, 2010b: 14). To this end, non-compliance with the relevant legislative frameworks that govern public finance management by many government departments in the Eastern Cape provincial government is a major challenge hindering the work of the AG.

\section{Technical challenges}

The office of the Auditor-General is facing a number of technical challenges in executing its oversight role of promoting financial accountability. Technology is extensively used in the office of the Auditor-General. Information and communication technology (ICT) supports computers used in auditing. According to the AG (2010a: 65) the networks that connect the offices of the AG across the country are used for electronic communications such as conferencing facility. Nevertheless, these have come under pressure due to the increased number of users and applications that use them (AG, 2010a: 65). Another 
technical challenge facing the office of the AG is that information technology (IT) staff who are technically competent are hard to find (AG, 2010a: 66).

Moreover, the AG (2012: 75) provides that during the 2011-12 financial year, IT governance practices and structures were inadequately designed at $60 \%$ of the Eastern Cape Provincial entities. Weaknesses ranged from IT strategic plans not having been developed and IT steering committees not having been established (AG, 2012: 75). Additionally, IT service continuity controls such as business continuity, backups and disaster recovery plans (DRPs), was not designed at $71 \%$ of the provincial departments (AG, 2012: 75). The AG (2012: 77) argues that the major reasons for IT control weaknesses in the Eastern Cape Province includes, IT not being treated as a strategic priority, IT sections not adequately capacitated to fulfil IT control obligations adequately due to skills shortages, inadequate oversight responsibility by provincial structures (provincial government IT officers and the provincial treasury) to ensure the development and implementation of policies and procedures relating to IT service continuity, among others. All these weaknesses impede the office of the Auditor-General to effectively perform its responsibilities.

\section{Recommendations}

Based on the findings of this study, it is clear that the office of the AG is facing copious challenges in performing its duties in the provincial sphere of government. This section offers some recommendations that can be useful in addressing these challenges.

It is recommended that there is need for continuous support from other agencies and stakeholders. Although the AG has good relations with other oversight institutions, there is still a need for the $A G$ to facilitate and strengthen maximum relations between the office of the AG and other oversight institutions such as the Public Protector. Good cooperation and relations are crucial for sharing information and to strengthening the fight against fraud, corruption and other aspects of financial misconduct in the public sector. There is need for collaboration and support from stakeholders at national, provincial and local spheres of government. The major constraint faced by the AG is that some institutions that are supposed to be partners in fostering financial accountability delay or completely ignore the AG's recommendations. There is a lukewarm enthusiasm 
on the part of Parliament towards recommendations made by the office of the AG. There is need to consider reports timely and exhaustively by the relevant authorities. This is underscored by Hanekom and Thornhill (1986: 115) who argue that "if the compliers of reports know that they are to be analyzed in detail, they are often encouraged to provide a faithful review of their activities," and the opposite is also factual. When the Auditor-General's reports and recommendations are sent to Parliament, members of Parliament need sufficient technical capacity to understand them and adequate political motivation to ensure that the executive acts on the recommendations. To this end, Parliament must ensure that the recommendations made by the AG are implemented to complete the circle of accountability and thereby promoting financial accountability.

In relation to late submission of financial statements for auditing, heavy penalties should be set on departments which submit their financial statements at the eleventh hour. For this measure to be effective the office of the AG must be given some power to prosecute offenders. Furthermore, it can be recommended that there is need for allocation of more resources to the office of the AG by national government. Currently the AG relies on audit fees; this institution needs to have some allocation from the government budget. The office of the AG requires adequate funding, equipment and facilities. In this regard, government needs to recognize the costs as well as the high returns of audits and provide appropriate funding. More so, it is recommended that the AG has to continuously make efforts to raise employee satisfaction by providing better remuneration practices, fostering better working relations among staff and reducing recruitment of under-qualified and inexperienced personnel. This will also help curb the challenge of high staff turnover at the office of the AG. Additionally, the office of the AG should consistently consider its compensation parameters so as to retain and even attract a highly qualified and competent workforce.

Lastly, it is recommended that the departments, institutions, and the public servants in the Eastern Cape Provincial government should be committed to provide excellence public service to the citizens. Hilliard (1995: 70) concurs that a new loyalty towards the public service should be fostered in order to streamline the quest for service excellence and to promote the cause of total quality management. All the political leadership in the Eastern Cape Province should rally behind the AG, rendering their support to the institution and ensure that the recommendations from the AG are seriously considered. In this regard, financial accountability must be the responsibility of everyone. 


\section{Conclusion}

This article provided a critical analysis of the oversight role of the office of the AuditorGeneral in financial accountability in the Eastern Cape Provincial government. The results of the study indicate that the Auditor-General has a crucial role in promoting financial accountability in the provincial sphere of government. However, there are many challenges threatening the work of the office of the Auditor General. The challenges facing the office of the Auditor-General are both internal and external - retention of staff, debt collection, cost of auditing, political challenges, weak internal systems in some government departments, non-compliance with legislation and technical issues have been identified as some of the main challenges.

The action suggested includes the need for continuous support from other relevant agencies and stakeholders, there is need to consider reports timely and exhaustively by the relevant authorities, imposing heavy penalties on departments that submits reports for auditing at the eleventh hour; allocation of more resources to the office of the Auditor-General and follow ups to ensure that the recommendations made by the Auditor-General are being implemented. This article concludes that, financial accountability is the cornerstone of democracy and a precept of good governance. The office of the Auditor-General is a state institution that exists to strengthen constitutional

democracy and it plays an important role of promoting financial accountability in the Republic.

\section{List of References}

- Auditor General. (2007) Annual Report of the Auditor General 2006-2007. Pretoria: Government Printer.

- Auditor General. (2008) Annual Report of the Auditor General for the Financial Year 20072008. Pretoria: Government Printers.

- Auditor General. (2009a) Budget and Strategic Plan of the Auditor General of South Africa for 2009-2012. Pretoria: Government Printers. 


\section{Africa's Public Service Delivery \& Performance Review}

- Auditor General. (2009b) General Report on the Provincial Audit Outcomes of Eastern Cape 2008-2009. Pretoria: Government Printer.

- Auditor General. (2010a) Annual Report of the Auditor General for the Financial Year 2009-2010. Pretoria: Government Printers.

- Auditor General. (2010b) General Report on the Provincial Audit Outcomes of the Eastern Cape 2009-2010. Pretoria: Government Printers.

- Auditor General. (2011a) Annual Report of the Auditor General for the Financial Year 2010-2011. Pretoria: government Printers.

- Auditor General. (2011b) General Report on the Provincial Audit Outcome of the Eastern Cape Local Government 2010-2011. Pretoria: Government Printer.

- Auditor General. (2011c) Strategic Plan and Budget of the Auditor General of South Africa for 2011-2014. Pretoria: Government Printer.

- Auditor General. (2011d) Consolidated General Report on the Audit Outcomes of Local Government 2010-2011. Pretoria: Government Printer.

- Auditor General. (2011e) General Report on the Provincial Audit Outcomes of the Eastern Cape Provincial Government 2010-2011. Pretoria: Government Printer.

- Auditor General. (2012) General Report on the Provincial Audit Outcomes of Eastern Cape Provincial Government 2011-2012. Pretoria: Government Printer.

- Erasmus, C. B. and Visser, P. W. (2002) The Management of Public Finance: A Practical Guide. Cape Town: Oxford University Press Southern Africa.

- Fox, W. and Meyer, I. H. (1995) Public Administration Dictionary. Kenwyn: Juta and Company.

- Hanekom, S. X. and Thornhill, C. (1986) The Functions of the Public Administrator. Durban: Butterworth Publishers.

- Hilliard, V. G. (1995) Performance Improvement in the Public Sector. Pretoria: Van Schaik.

- National Parliament of the Republic of South Africa. (2012) Announcements, Tabling and Committee Reports. Pretoria: Government Printer.

- Obto, H. (2005) Establishment of the INTOSAI Professional Standards Committee. International Journal of Government Auditing, 32 (4) 1-4. 
- Ramkumar, V. and Krafchik, W. (2005) The Role of Civil Society Organizations in Auditing and Public Finance Management. Available at: http://www.internationalbudget.org/wpcontent/up/c (Accessed 13 August 2013).

- Republic of South Africa. (1995) Auditor General Act, 1995 (Act No. 12 of 1995). Pretoria: Government Printer.

- Republic of South Africa. (1996) Constitution of the Republic of South Africa. Pretoria: Government Printer.

- $\quad$ Republic of South Africa. (1999) Public Finance Management Act, 1999 (Act No. 1 of 1999 as amended by Act No. 29 of 1999). Pretoria: Government Printer.

- Republic of South Africa. (2003) Municipal Finance Management Act, 2003 (Act No. 56 of 2003). Pretoria: Government Printer.

- Republic of South Africa. (2004) Public Audit Act, 2004, (Act No. 25 of 2005). Pretoria: Government Printer.

- Sahgal, V. and Chakrapani D. (2003) Clean Government and Public Financial Accountability. World Bank Operations Evaluation Department (OED) Working Paper Series No. 17. Washington D. C: The World Institute.

- Van der Waldt, G, Van Niekerk, D, Doyle, M, Knipe, A, and du Toit, D. (2002) Managing for Results in Government. Sandown: Heinemann Publishers.

- Van Niekerk, D, Van der Waldt, G, and Jonker, A. (2002) Governance, Politics and Policy in South Africa. Cape Town: Oxford University Press.

- Visser, C. B and Erasmus, P. W. (2002) The Management of Public Finance. Cape Town: Oxford University Press.

\title{
AUTHORS' CONTACT:
}

\author{
NZEWI Ogochukwu \\ Dept of Public Administration \\ University of Fort Hare \\ Email: onzewi@ufh.ac.za
}

MUSOKERU Prosper

Dept of Public Administration

University of Fort Hare 